\title{
FROM CREATIVE ACCOUNTING PRACTICES AND ENRON PHENOMENON TO THE CURRENT FINANCIAL CRISIS
}

\author{
Dana Simona Gherai ${ }^{1}$ \\ Diana Elisabeta Balaciu ${ }^{2}$
}

\begin{abstract}
The aim of this paper is to bring into attention the creative accounting phenomenon. Types of creative accounting practices has been examined comparing scandals occurred in large companies in the last two decades. In order to realize this scope we define the concept of creative accounting and its various forms, and we try to figure the reasons why we came into a financial crisis again, even if the history taught us that the risks are very large. We discuss the implication of creative accounting in the current financial crisis because many financial enterprises have sought state support within a short period of receiving unqualified audit opinion. The research method is a deductive one, fundamental type that give us the necessary prerequisites for future research. We believe that creative accounting practices will not disappear unless the causes which have given rise to them will disappear, too. Therefore, although driven by the intention to limit creative accounting, the accounting normalisers must take into account the circumstances that allow its expression under close supervision.
\end{abstract}

Key words: creative accounting, fraud, audit, financial statements.

JEL codes: M41, M42, M49

\section{Introduction}

Periods of crisis represent in fact tests for companies and managers who are tempted to resort to ingenious methods, often questionable, in order to improve the presentation of financial statements. Overall, there is a trend and a fierce desire to perform certain activities so as to manipulate the figures, financial statements and performance reports, to distort the true image (,true and fair view"). Consequences and negative impact come quickly, first on investors who are misled about the true overall situation of the society, as well as on companies that actually carry out the economic activities. The Enron phenomenon, Parmalat, WorldCom, Xerox, Ahold Royal, or Equitable Life bankruptcy are few examples of accounting scandals that have left traces in the history of this profession due to their strong impact.

In an uncertain world, full of incidents with major financial losses resulting from an abusive creative accounting, the professional accountants, just like auditors, must provide soothing comfort to the parties interested in the fact that "provides an external and objective check on the way in which the financial statements have been prepared and presented, and it is an essential part of the checks and balances required. . . Audits are a reassurance to all who have a financial interest in companies" (Committee on the Financial Aspects of Corporate Governance, 1992, p. 36). Auditors try to create themselves an image of independent individuals who, due to the professional experience, may provide fair opinions, accounts checked independently and objectively to the extent to which to enable the investors and the market to manage the risks they are facing up. However, the assertions on auditors are challenged sometimes because of capitalist economies that are crisis-prone.

\footnotetext{
${ }^{1}$ University of Oradea, Faculty of Economics, Romania, e-mail: dana.gherai@yahoo.com

${ }^{2}$ University of Oradea, Faculty of Economics, Romania, e-mail: dianabalaciu@yahoo.com
} 
Creative accounting emerged in Anglo Saxon literature, since the 1970s, most often in works regarding business bankruptcy. Watts and Zimmerman $(1978,1986,1990)$ are those who set the basis of the positive accounting theory. This research trend was the subject of several empirical works that sought to explain the accounting choices based on issues regarding the political costs that companies are facing up. Colasse B. (1995) states that "there isn't any true result, but an arranged one using the creative accounting techniques", defining it as a cluster of accounting information practices, within the law, practiced by certain economic entities in order to embellish the image of financial position and the economic and financial performance. He also highlights the fact that these practices occur as a result of normalisation limits, but also as a consequence of the fact that human creativity knows no boundaries.

Unlike creative accounting, fraud comes from an illegal act; the difference between the two consists of the illegal and deliberate nature of the act that caused the damage. IFAC defines fraud as "a deliberate act committed by one or more individuals within the board, people in charged with governing the employees, or third parties, involving the use of deception to obtain an unjust or illegal advantage (IFAC 2009)". Brown P.R. (1999) confines it as forgery, alteration or destruction of documents, registration of false operations or concealing important information.

\section{Research methodology}

In our paper, types of creative accounting practices has been examined comparing scandals occurred in large companies in the last two decades. Within this framework, we define the concept of creative accounting and its various forms, and we try to figure the reasons why we came into a financial crisis again, even if the history taught us that the risks are very large.

The method of research is an deductive one, fundamental type that give us the necessary prerequisites for future research, particularly the next target we want to achive is an empirical study on detecting the existence and influence of creative accounting practices of the Romanian companies listed on BSE (Bucharest Stock Exchange).

\section{From creative accounting practices...}

"It would be wrong to believe that regulation and normalization render objectively the accounting portrait of the company. They reveal, explicitly, only the manner in which this portrait was painted. On the other hand, they leave to account preparatory room for manoeuvre, while essential and irreducible, that they can use according to considerations deriving from the financial or communication policy of the company" (Colasse, quote by Raybaud - Turillo and Teller, 1996). Also, MacBarnet and Whelan (1999) stated that all financial engineering used to create the desired image or representation is called creative accounting instruments. Shah (2000) focuses on enterprise management using breaches or ambiguities within legislation so as to create the company's portrait according to their preferences; in other words, financial performance is achieved by exploiting breaches within legislation, strengthening the idea that creative accounting is not breaking the law, only its spirit.

Although there are disagreements regarding the definition of creative accounting, most researchers agree that it distinguishes in two aspects. The first aspect concerns the use of professional accountants' imagination to translate these legal, economic and financial innovations that do not exist, at the time of their occurrence, normalized accounting solutions, and the second aspect reveals that the resulting arrangements which emerge from this financial engineering are initiated depending on their incidence upon the balance sheet and the results of the company. The current legal and accounting system is considered to be a permissive one, allowing companies a greater flexibility in the way they can treat various accounting issues and make decisions regarding the accounting policies they deem most appropriate to be applied by them. This flexibility is agreed by professional accountants, who have created also a good framework in order to "speculate" the accounting legislation and to practice creative accounting. Besides flexibility, according to the 
opinion issued in 2002 by Cominskey, the implementation period of transactions is seen as another area of creative accounting emergence, thus it can be elected according to the date on which the entity wants to improve the image of certain accounts. The example that is to be found very often in literature is related to Enron case, a company that used a lot about this procedure in order to achieve the desired financial goals (Johnson. 2002). In 2003 in the book „The Smartest Guys in the Room” is outline that, "the Enron scandal grew out of a steady accumulation of habits and values and actions that began years before and finally spiraled out of control" (McLean and Elkid, p. 132-133).

Remaining in the sphere of serious accounting scandals within important companies (World Com, Xerox) and the banking sector (BCCI, Barings, Allied Irish Bank şi Baninter), Mine Omurgonulsen and Ugur Omurgonulsen (2009) raises the issue on creative accounting with its legal and illegal sides that have appeared on the agenda of important companies and governments. They examine a particular type of creative accounting practices (fraud) in the light of a Turkish case, ImarBank. According to Smith ( 1992), the expression of directions related to creative accounting practices are to be found as being oriented towards: asset purchase preparatory operations using the merger method; transactions between the parent company and its subsidiaries; extraordinary events; off-balance sheet items; contingent liabilities; capitalization of costs; changing depreciation methods; evaluating the output stocks of the entity; currency operations; debt costs; social contributions; operations on financial assets.

Annual financial statements represent the basic form in publishing the accounting information, aimed at providing information on the financial position, performance and cash flows of a company, useful to a wide range of users in making economic decisions. The third-level role of annual financial statements on using the information for their users can be structured as follows:

- explanatory, with reference to the business practice and accounting practice;

- normative, assessment of business management;

- projected, providing the search for solutions to new issues arising in the field.

James Bodurtha, Jr., outline that, "From late 1997 until its collapse the primary motivations for Enron's accounting and financial transactions seem to have been to keep reported income and reported cash flow up, asset values inflated, and liabilities of the books." (James Bodurtha, 2003 p.2). The balance sheet is the summary document that renders the status of the financial situation and allows passing judgments on the performance and risk associated with a company, as well as the assessment of future cash movements (Feleaga, 1996). For this reason, companies are tempted to try improving the balance sheet structure. The presented manipulation techniques are meant to improve the balance sheet in particular. These techniques act on one or more of the following: equity, debt, need of working capital, treasury. The issue raised by the analysis of intangible assets is that there are few reporting requirements and often they are imprecisely. Traditionally, the research and development $(\mathrm{R} \& \mathrm{D})$ costs have represented the only item of expenditure for intangible assets that was presented in the financial statements of the economic entities so that these R\&D costs were the object of several academic efforts. However, there are few important results. Thus, there is a significant impact on cost-benefit ratios when the R\&D costs incurred are adjusted to equivalent capital shares. In the case of industries performing intensive research and development activities, the capitalization effect on research and development can reduce that ratio by more than half. Company WorldCom, which considered operating expenses as investments, recognising them as assets. This accounting treatment resulted in increased income calculated by the company and the reporting of non-existent profits.

The accounting world has debated for long time the decision to move intangible assets on expenses or to capitalize them. There has been organised enough empirical research to test the hypothesis according to which capitalization of intangible assets would increase the usefulness of accounting situations, which is measured generally as the ability to explain stock prices through earnings and book values. For example, researchers Dennis Chambers, Ross Jennings and Robert Thompson (2003) have conducted a study which shows that depreciation and discretionary 
capitalization increase the relevance of financial statements. The companies have preferred to pass the intangible investments on expenses as they are performed, reducing immediately the entire amount from revenue, unlike investment capitalization, and allocating revenue only through regular depreciation of assets. One way to do this is by over-allocating costs for research and development "in progress". In the case of procurement, GAAP allows the purchaser to immediately withdraw from the balance sheet the expenditure made by the purchasing company in connection with the development of a new product. According to Baruch Lev (2001): "The main players in the field of information - managers, auditors, and financial analysts - are not generally disturbed by the current disclosure framework (rather non-disclosure) of intangible assets. The immediate transition of research and development performed internally, or purchased, on expenditure, is a recipe for future enhancement growth of reported profits". While under GAAP standards, ongoing research and development are immediately recorded on expenses, based on the IFRS standards the research and development are capitalized and depreciated. Standards development committees of the two agencies recognize the need to bring closer the standards, but nowadays these differences still exist. Strict enforcement of the precautionary principle whereby assets must be assessed at historical cost may have an impact on a company's financial position. Therefore, in some countries, accounting normalisers authorize the re-assessment of tangible assets under certain conditions. This approach leads to the proliferation of manipulative techniques that have as consequence the artificial increase of equity and debt capacity.

According to Tabără N (2000), a representative example in this respect is the case of Ruperth Murdoch Corporation that took advantage of the Australian accounting principles tolerance in order to review its news headlines and other intangible assets, thus avoiding to be put in a difficult situation by bankers through the immediate repayment of loans. Another example is the Enron Company, which, in order to determine the equitable value of unproductive assets, sold a part of these to another entity at a higher price than their real value using the sales price as a benchmark to determine the correct value. The result was represented by reports on profit from the sale of $\$ 67,000,000$ and the other unproductive assets were recorded in the balance sheet with the overestimated values.

Through variables such as differences in reassessment, the reassessment of tangible assets provides the basis for depreciation and the depreciation period, opportunities to manipulate the image of balance sheet. Reassessing the tangible assets, a company can survive to a significant decrease of equity due to losses; it can have medium or long term consequences on the result of the exercise; an increase in the depreciable base takes place and therefore, an increase of future depreciation, having an impact on reducing the result. To avoid this effect, some companies charge the excess of depreciation to the difference resulting from reassessment, which limits the depreciation expenditure at the value that would have been accounted for, if the fixed asset was maintained at the cost of aquisition (Feleaga, 1999).

A favourable ground for the expression of creative accounting practices is the irreversible impairment of fixed assets. The periodical comparison of the net accounting value to the recoverable amount is a requirement imposed by IAS 36 for the recognition of an asset impairment loss. The difference between the two values allows opportunities for manipulating the result. At the basis of the chosen depreciation policy, there can be identified three variables that allow the influence on the company's performance i.e.: the depreciation period, the depreciation method and residual value, which will be analysed in the following examples. The board of a company sets the appropriate useful life and the residual values related to the fixed assets. If the governing bodies take advantage of this flexibility in an aggressive way, seeking to artificially increase earnings, either by setting service lives too high or too increased amounts of the residual value, it is reached a situation where the depreciation charges would be underestimated. Consequently, the current result will be overestimated, as well as the book values of the assets involved. In the event that, at a later 
date, it is found that those book values are higher than the net cash flows which are not updated and will be obtained by using the assets, a viable solution is represented by reducing these.

Thus, different options on the useful life lead to various depreciation costs, namely different perspectives on the result. Reviewing the useful life leads to adjustment of depreciation charges corresponding to the current period and future periods.

In conclusion, when making a comparison regarding the performance of several companies on the current (or operating) result, it is necessary to start from the assumption that the depreciation periods are comparable, or to disregard depreciation, comparing for example the gross operating surplus.

Choosing a certain depreciation method related to the company's accounting policy in order to assign systematically the depreciable amount of an asset during its useful life has an impact on the profit and loss account. Thus, various depreciation methods have a different impact on the result. Depending on the chosen method, the distribution of expenses on depreciation changes in time:

- straight-line method leads to constant depreciation charges over the useful life;

- SOFTY method leads to higher depreciation charges within the first years of operation, allowing the establishment of higher investment funds, especially in this period when the taxable income is lower and therefore the corporate tax decreases too;

- progressive method (opposed to SOFTY method) leads to a higher result at the beginning of the useful life and a lower result at the end of it;

- diminishigg method consists of a decreasing expenditure with depreciation!over the useful life.

\section{... And Enron phenomen...}

Year 2002 for the accounting profession has left "deep traces" in the history, American corporate collapses like Enron, WorldCom, Tyco are just a few name which turned the attention of entire world on accounting firms, accounting practices and audit practices. The impact of Enron collapse was greater because it was closely followed by the bankruptcy of WorldCom Company, both in the United States of America, then a series of similar scandals, Ahold Royal in the Netherlands and Equitable Life insurance company in the UK, all these showing that this was not just a U.S. phenomenon and the accounting and auditing practices have been widely condemned.

During crisis, the confidence in financial reporting, audit reports and regulations governing the professional accountants' work are decreasing considerably. Great efforts to streamline and improve the old rules, to implement and develop new rules are supported by all countries affected by the bankruptcy crisis, as well as those who "have watched" the consequences of mistakes in the background.

Requests and proposals for further reforms in the accounting and audit field were necessary ,in a characteristic move, the Securities and Exchange Commission and the public accounting profession have been among the first to respond to the Enron crisis. Unfortunately, and sadly reminiscent of financial disasters in the 1970s and 1980s, this response will likely be viewed by investors, creditors, lawmakers and employees of Enron as "too little, too late" Thomas (2002). Thus the Law Sarbanes-Oxley from 2002 is one of the reforms that has repercussions throughout the world by adopting the standards belonging to foreign trade companies in the U.S. market and determination of other nations to study its provisions and act on his own benefit, example: Institute of Chartered Accountants from New Zealand has issued a document titled "Corporate Transparency-Making Markets Work Better", and the Institute of Chartered Accountants from Australia contributed to the development and release of the "Australian Stock Exchange Corporate Governance Council Principles of Good Corporate Governance and Best Practice Recommendations", the United Kingdom responded with the "Turnbull Report on Internal Control: Guidance for Directors of Listed Companies Incorporated in the UK". 
The consequences were large, Low M., (2008) illustrates the role that accountants have played in these "achievements":

- Enron: accounting/off balance sheet contrivances; chief financial officer indicted; company bankrupt; billions of equity value lost;

- Tyco: chief executive officer charged with tax evasion, waste of corporate assets; massive charge of $\$ 6$ billion to earnings after disposal of CIT unit;

- WorldCom: $\$ 3.8$ billion fraud; loans to chief executive officer; bankruptcy;

- Adelphia Communications: off balance sheet loans to senior officers;

- Xerox: accounting overstates profits by $\$ 1.4$ billion;

- Global Crossing: filed for bankruptcy after fiddling accounts;

- Qwest Communications: chief executive officer resigned; profits restated, assets cut by $50 \%$, or $\$ 34$ billion; share price down;

- Health South: $\$ 1.4$ billion fraud; false entries created in income statements and balance sheets;

- $\$ 110$ billion merger of AOL and TimeWarner cemented with inflated accounting of AOL revenues; within 18 months, company value declined $75 \%$, and massive write-downs of asset values were taken - AOL's 2002 earnings were written down by $\$ 98.7$ billion (a figure only slightly smaller than the European Union's budget for 2003); civil litigation ensued for damages to investors;

- Bristol-Myers: restates $\$ 2.5$ billion in sales and $\$ 900$ million in profits after inflating distributor's stock levels; settles antitrust lawsuits for a cost of $\$ 670$ million;

- Vivendi-Universal in France: failure of strategy; loss to shareholders; class action suits filed alleging misrepresentation of company's financial realities;

- Ahold in The Netherlands: chief executive officer fired and stock price collapsed after American subsidiary was found to have falsely reported earnings;

- HIH insurance group in Australia: failed with debts of $\$ 3.1$ billion after consistently understating claims liabilities; chief executive officer, among other things, spent A $\$ 340,000$ on gold watches in 1 year; criminal and civil charges pending against several directors;

- SK Global in South Korea: overstates 2001 earnings by $\$ 1.2$ billion; liquidity crisis caused for credit card companies; $\$ 10$ billion pulled by investors from investment trusts; (pp. 3840, Reprinted with permission of the publisher. From Moral Capitalism, Copyright @(2003) by Stephen Young, Berrett-Koehler Publishers, Inc., San Francisco, CA. All rights reserved. www.bkconnection.com).

The spectacular collapse of Enron Company provides a vivid image of the fact that some companies may use the legal form of transactions to hide the underlying economic substance of these transactions.

\section{...To the curent financial crisis.}

On this time the states are going through a financial crisis which force the state to intervene to save the banks, the financial institutions from failure. In 2007 the subprime mortgage market from United States which boomed between 2001 and 2006, began to collapse. The Western and the US economies used financial instruments which created an abundance of credit and encouraged excessive risktaking (Ferguson, 2008). It seems that banks lost around US\$2.8 trillion (Bank of England, 2008) because of the hedge funds and insurance companies which were key actors in the financialisation of the economy. Public money are being used to prop-up distressed financial enterprises because London Scottish Bank has been closed, Northern Rock has been nationalised, The European Central Bank has provided around $€ 467$ billion to support banks, the US government has closed 22 banks, including Lehman Brothers, Washington Mutual and Indymac and so on. 
In this conditions questions about the role and value of external audits are normal to appear. Financial institutions collapsed or had to be saved after they received unqualified audit opinion; some examples are Lehman Brothers with an unqualified audit opinion on 28 January 2008 on its annual accounts, and by early September filed for bankruptcy, also Bear Stearns received an unqualified audit opinion on 28 January 2008 and by March appeared its financial problems (US Securities Exchange Commission, 2008; The Guardian 15 March 2008).

All this events wake suspicions and encourage reflection regarding the role, independence and the objectivety of the auditors (Sikka, 2009).

\section{Conclusion}

The effects of the financial crisis which emerged at international level are being felt even nowadays: bankruptcies, investor's risk aversion, low liquidity, tightening credit conditions, price volatility are just some expressions of the phenomenon entitled "crisis". In these circumstances one should pay attention to financial statements, persons involved in drafting them, as well as those who are in charge with providing them. The responsibility for drafting and presenting the financial statements represents the duty of the company's management team, so that solutions to improve the perception and the situation regarding the financial statements should be found at this level and consist of self-imposed improvements regarding accounting policies and methods that are to be applied within the current activity because as long as it will just trigger major incidents which demonstrate the fact that, in most cases, huge financial losses were the direct result of abusive creative accounting, it will not find followers to support flexibility in the accounting field and it will act so as to restrict it.

It is unreasonable and difficult to suggest to the management boards of all companies to waive immediately all creative accounting practices they have been using so far. No doubt that all the companies need to maintain some flexibility in their accounting activity. However, this flexibility must be tempered by a strong dose of realism, removing any temptation to exploit the arising opportunities. Moreover, these opportunities intend to encourage a more accurate presentation of results, and not to distort them.

Creative accounting practices will not disappear unless the causes which have given rise to them will disappear, too. Therefore, although driven by the intention to limit creative accounting, the accounting normalisers must take into account the circumstances that allow its expression under close supervision.

\section{References:}

1. Bank of England 2008, Financial stability report: No. 24, October 2008. London: Bank of England, http://www.bankofengland.co.uk/publications/fsr/2008/fsrfull0810.pdf, accessed at 10.03.2011

2. Baruch Lev, 2001. Intangibles: Management, Measurement, and Reporting. Washington DC, The Brookings Institution Press.

3. Chambers Dennis, Jennings Ross G., and Thompson Robert, 2003. Managerial Discretion and Accounting for Research and Development Costs. Journal of Accounting, Auditing and Finance 18, pp. 79-113.

4. Committee on the Financial Aspects of Corporate Governance (1992). The financial aspects of corporate governance (Cadbury report). London: Gee.

5. Feleagă N, 1996, Controverse contabile, Editura Economică București

6. Ferguson, N., 2008. The ascent of money: A financial history of the world. London: Allen Lane. 
7. James N., Bodurtha Jr., 2003. „Unfair Values” - Enron's Shell Game. Washington, D.C. p. 2. http://citeseerx.ist.psu.edu/viewdoc/download?doi=10.1.1.126.7560\&rep=rep1\&type=pdf. accessed at 11.03.2011

8. Johnson C, 2002. Senate Panel says 2 banks helped Enron hide loans. Washington Post, Wednesday, July 24, Page E01, http://washingtonpost.com/ac2/wp-dyn/A53153-2002Jul23 accessed at 20.03.2011

9. MacBarnet D., Whelan C., 1999. Creative Accounting and the Cross-Eyed Javelin Thrower. Blackwell Publishers.

10. Mary Low, Howard Davey, Keith Hooper, 2008. Accounting scandals, ethical dilemmas and educational challenges. Critical Perspectives on Accounting 19, p. 226.

11. McLean B., Elkind P., 2003. The Smartest Guys in the Room. pp. 132-133.

12. Mulford Ch, Comiskey E., 2002, The finanacial numbers game Detecting creative accounting practices, JohnWiley\&Sons, Inc ISBN 10-0-471-77073-6

13. Omurgonulsen M., Omurgonulsen U., 2009. Critical thinking about creative accounting in the face of a recent scandal in the Turkish banking sector. Critical Perspectives on Accounting, Volume 20, Issue 5, Pages 651-673.

14. Order nr 3055/ 2009 for approval of accounting regulations with European Directives.

15. Sikka P., 2009. Financial crisis and the silence of the auditors. Accounting, Organizations and Society 34.

16. Raybaud Turillo B., Teller R., 1996. Comptabilite creative, Economica, Paris.

17. Tabără N., Horomnea E., 2000, Analiza contabil-financiară în perspectivă internațională, Contabilitatea, expertiza şi auditul afacerilor, nr.11, Noiembrie 2000, pag 1

18. Thomas CW, 2002. The rise and fall of Enron. Journal of Accountancy. http://www.journalofaccountancy.com/Issues/2002/Apr/TheRiseAndFallOfEnron.htm accessed at 18.03.2011

19. US Office of Federal Housing Enterprise Oversight, 2006. Report of the special examination of fannie mae. Washington DC http:// www.ofheo.gov/media/pdf/FNMSPECIALEXAM.PDF>.

20. US Securities Exchange Commission, 2008. SEC's oversight of bear stearns and related entities: The consolidated supervised entity program. Washington, DC: SEC <http://finance.senate.gov/press/Gpress/2008/ prg092608i.pdf>.

21. Watts R.L., Zimmerman J.L. 1990. Positive Accounting Theory. A ten year perspective The Accounting review, vol 65, no 1, pp. 131-156, available at http://www.jstor.org/stable/247880?\&Search=yes\&searchText=Watts\&list=hide\&searchUri= $\% 2$ Faction\%2FdoBasicSearch\%3Ffilter\%3Diid\%253A10.2307\%252Fi302530\%26Query\% 3DWatts\%26Search.x\%3D0\%26Search.y\%3D0\%26wc\%3Don\&prevSearch=\&item =1\&ttl= $5 \&$ returnArticleService=showFullText accessed at 12.03.2011 